\title{
A METHODOLOGY TO STUDY PEDAGOGICAL EDUCATION OF UKRAINE: THE REGIONAL DIMENSION
}

\author{
Tetiana Zuziak \\ Vinnytsia Mykhailo Kotsiubynskyi State Pedagogical University, Ukraine \\ Oleksandr Lavrinenko \\ Ivan Ziaziun Institute of Pedagogical and Adult Education \\ of the National Academy of Educational Sciences of Ukraine, Ukraine \\ Oksana Marushchak \\ Vinnytsia Mykhailo Kotsiubynskyi State Pedagogical University, Ukraine \\ Larysa Semenovska \\ Poltava V.G. Korolenko National Pedagogical University, Ukraine \\ Oksana Klochko \\ Vinnytsia Mykhailo Kotsiubynskyi State Pedagogical University, Ukraine
}

\begin{abstract}
Aim of the research is to validate the methodological approaches, developed by the authors, for the further use in the studies on historical pedagogy that within the regional aspect examine the processes of emergence of pedagogical education in Ukraine. For highlighting the issues of methodology of the historical and pedagogical research within the regional dimension, contemporary scientific approaches were used, including the integrated, systematic, activity, and synergic ones. The principles of objectivity, evidence, comprehensiveness, substantive analysis, of historical and logical coherence, of continuity, and systematic one were chosen as the main methodological grounds for the research. The study is novel in that it allows to assert: the mentioned methods of research with regard to its key concepts provide an opportunity to compare and trace the evolution and dynamics of development of the pedagogical education of the region within the defined chronological frame, shaping it as a complex, controversial process, influenced by many factors. The results prove that a research on pedagogical history should be grounded in holistic, historical and chronological, systematic, paradigm, structural, functional, axiological, and cultural studies approaches, be science-based, historically accurate, congruous with nature and culture. Within the scope of these approaches and principles, appropriate research methods should be used, i.e. empirical, general-science and specialized ones.

Keywords: historical and regional dimension, history of the pedagogical education of Ukraine, methodology, principles and methods of research, research concepts, theoretical and methodological basis.
\end{abstract}




\section{Introduction}

Modern historical and pedagogical science of Ukraine in recent decades has made significant progress in developing the latest scientific and methodological approaches that contribute to the analysis of the formation and development of education in individual regions. It should be emphasized that the regional component of historical and pedagogical research is becoming increasingly popular because it allows a comprehensive approach to solving current problems of pedagogical education as not only a socio-political phenomenon, but also a complex cultural phenomenon in the unity of specific patterns of its development. It should be noted that in the Ukrainian historical and pedagogical science today is active scientific community, whose representatives develop basic methodological approaches to the development of pedagogical regionalism, emphasizing the importance of regional research in practical and theoretical dimensions, outlining historical and pedagogical regionalism as relevant and necessary direction in research.

Correspondingly, the issues of methodology of the studies on historical pedagogy in regional dimension become increasingly topical and important. Careful examination and theoretical validation of such methodology will contribute to solving a number of problems, including the practical application of knowledge of historical pedagogy, as well as better potential for prognosis etc. Aim of the research is to validate the methodological approaches, developed by the authors, for the further use in the studies on historical pedagogy that within the regional dimension examine the processes of emergence of pedagogical education in Ukraine.

\section{Research Methodology}

Methodology of the research is based on using special instruments that contributed to reaching the main objectives and achieving the aim of research by covering the broad spectrum of scientific and specialized pedagogical sources, publications on history and pedagogical history, periodicals, archival documents, etc. While highlighting the issues of methodology of the historical and pedagogical research within the regional dimension, contemporary scientific approaches were used, including the integrated, systematic, activity, and synergic ones that enabled to systematically and thoroughly study and afterwards to use a single integrated model of an object at all stages of the research. The principles of objectivity, evidence, comprehensiveness, substantive analysis, of historical and logical coherence, of continuity, and systematic one were chosen as the main methodological grounds of the research. The categories of dialectics (essence and phenomenon; cause and effect; necessity and eventuality; chance and reality; 
content and form; the part and the whole; the individual and the common, etc.) played an important role in the study of methodology of Ukrainian pedagogical education progress. These categories contributed to a deeper understanding of the complex issues of pedagogical progress, to creative solving of such problems. The results of the conducted pedagogical study were to meet following methodological requirements: objectivity, probability, reliability, and validity. Methodology of the research is based on the specific scientific forms that are manifested in orientation towards the system of knowledge, produced by the scientific schools, with certain explanatory principles and ways of organization.

In recent years, prolific group of researchers has emerged in Ukrainian historical and pedagogical studies; their works may rightfully be considered a valuable contribution to the theory and methodology of pedagogy. The academic audience on the subject is well-familiar with publications, authored by O. Adamenko (2013), L. Berezivska (2011), N. Gupan (2013), N. Dichek (2014), I. Ziaziun (2011b), V. Kurylo \& Ye. Khrykov (2013), O. Sukhomlynska (2003), which deal with the rationale for new methodological approaches. However, the core of pedagogical history within the regional dimension rarely becomes a subject for targeted research that, undoubtedly, has its impact on quality of historical and pedagogical studies in general.

\section{Research Results}

In order to solve the problem that is rooted in historical and pedagogical domain, findings in psychology, history, sociology, political studies, philosophy, art history, cultural studies, as well as historical regional studies and studies of the personalities of the prominent educators were used; however, that complicated the research process and assumed delving into specific terminology and phenomena. Exploring phenomena of regional pedagogical history within the defined chronological frame, it seems worth to use the leading methodological approach holistic one. Such approach, as emphasized by I. Ziaziun, should be a leading one in the studies on pedagogical history, as "integrity of the educational systems may be adequately described only using categories of interconnection, unity and integration" (Ziaziun, 2011b, pp. 19-20). We believe that is it reasonable to consider integrity of education as an inner criterion of its effectiveness. In practice, integrity of an educational system is most commonly evaluated according to its effectiveness. In the pedagogical research and innovative practices there are certain elements, links, stages and levels of education that serve as the common sense-generating, sense-producing "lines", namely, they are:

- Presence of a central sense-generating humanistic idea of education and compliance to it of the goals and values, stages and levels of education 
(with adequate regard to the specific circumstances of a certain level of education and real-life educational process).

- Interconnections, continuity, mutual complementarity and variability of content and results of the education.

- Compliance of the procedural aspects of educational process (its methods, educational techniques, environment) with the objectives, values and senses of education, as well as its content.

The use of the ideas of holistic approach while studying organizational forms, methods and tendencies of development of pedagogical education of Ukraine in a certain chronological period will contribute to distinguishing logics and consequent stages, to choosing the set of according research instruments, implementation of which would allow to state that it was the holistic approach that was used. The steps of holistic approach are:

- Studying the ideas of holistic, historical-chronological, systematic, structural-functional, paradigmatic, cultural studies, axiological approaches is aimed at producing some "conceptual lens" to be used during the further steps of the research; formulating an idea about the essence, functions, composition and structure of the phenomenon.

- Conducting a retrospective analysis through such "lens", with the mandatory adequate evaluation of its success and failures, achievements and losses of the mentioned approaches, assessment of the current state of the problem.

- Developing new perceptions about the essence, functions, compositions and structure, levels of some feature as a single phenomenon within some higher entity - personality as a whole (particularly through finding and analyzing its holistic traits - the ones that cause a personality to be oriented towards something and influencing the rest of its traits).

- Analysis of research publications and educational practice of solving the problem; revealing means and circumstances that favor achieving defined goals. Within the context of implementing holistic methodological approach the special attention should be turned to: means and circumstances enabling development of the main components of the researched problem; factors that are stimulating development of holistic traits of the researched pedagogical system; boundaries and conditions of realization of certain means' potential.

- Scoping and implementation of the model of holistic process of development of pedagogical education in Ukraine should: be a uniform "static structure of the process" (Ziaziun, 2011a, p. 20), this implies designing and realization of the whole sequence of research; reveal its 
holistic nature within the "dynamic structure of the process" (Ziaziun, 2011b, p. 29) that reflects the successive change of stages and phases of the process, which are aimed at development of the unsolved problems, at the favorable conditions and results; fulfill aspirations of the organizing entity (teacher or group of teachers) at all stages and in all circumstances of the holistic process.

To solve the vast number of problems regarding the essence of developmental trends of pedagogical education of certain regions of Ukraine, appropriate theoretical and methodological foundations ought be used in order to study and analyze a significant number of sources. As for methodological concept, it should be formed with regards to the principles of dialectical cognitive theory and to the ideas of synergy of methodological approaches. Among these approaches it would be productive, in order to study developmental trends of the pedagogical education of a certain region, to implement the following ones:

- Historical-chronological approach for substantiating periodization of development of pedagogical education, for exposing the essence of its main trends and characteristic features, applied to specific historical circumstances and given chronologically. It would allow to trace emergence, forming and development of the processes and arrange them chronologically, from emergence or conception of the idea through the main phases and up to decline or extinction. Embracing historical-chronological approach allows to determine prerequisites of development of pedagogical education as a system and to recreate its genesis. For instance, covering the changes within the system of pedagogical education in Podillia region of Ukraine during the late 18th through the early 20th century, it is important to emphasize that "these changes took place either amid certain reforms or in order to solve some practical problems (founding of parish secondary schools for women, secondary-class church parish schools and schools for teachers, seminaries, Vinnytsia Teachers' Training Institute; founding of a pedagogical study group; introducing pedagogy and didactics into the curriculum; solving practical problems of teachers' training)" (Zuziak, 2018, p. 4). Such transformation contributed to the renovation of the core of pedagogical education in Podillia region in the mentioned time frame. Historical-chronological approach facilitates achieving one of the main methodological requirements - understanding the subject of the research within its fundamental and historical background; this allows to view and analyze the development of educational processes, as well as the transformations of the academic and pedagogical principles of teaching and mentoring within certain historical environment and circumstances. 
- $\quad$ Systematic approach allows to holistically and thoroughly examine the progress of pedagogical education as an uninterrupted process of permanent change of its elements, with the evolution of these elements (aim of teaching, subject-subject relations, essence of learning, organizational process of pedagogical education and its results), depending of the level of concordance between them. Systematic approach implies that object of pedagogical history should be studied as whole, consisting of integrated elements and interconnections between them. Systematic approach facilitates showing integrity of the research object, while taking into account the influence of objective and subjective factors, including the foreign policy of the colonial states, their state organization and political order. While using the systematic approach, one should pursue looking for answers on the following questions: Which external factors case changes in functioning of the system of pedagogical education? Which principle changes took place within the system of pedagogical education of the researched period? Which other disciplines did influence its development? What results the researchers, scholars and educational practitioners have achieved? etc.

- Structural-functional approach facilitates theoretical analysis of the text for research purposes, identifying the whole aggregate of functional relation within the inner structure of pedagogical education, as well as determining levels and nature of its influence on the socio-cultural and civilization progress of certain territory or region.

- Paradigmatic approach ensures that development of pedagogical education is viewed as a systematic process, which defines the formation of the educational and pedagogical paradigms, dominant during the historical period.

- Cultural studies approach is aimed at writing a research on historical pedagogy within the framework of general philosophical understanding of culture. It urges to view pedagogical education of Ukraine as closely linked to the rich European and Ukrainian cultural heritage, their interplay and mutual enrichment. The choice of cultural studies approach to cover the research problem is motivated by the objective connection of educational and teaching activity with culture.

- Axiological approach is aimed on studying value dimensions and pedagogical ideals that permeate the process of development of pedagogical education; it urges to define value-sense priorities. As T. Zuziak (Zuziak, 2018) notes, preserving certain traditional values, rituals and customs in everyday life becomes a basis for revival of the nationally-oriented cultural life of the region or territory. 
At the same time, research should be generally science-based, historically accurate, objective, congruous with nature and culture, systematic, it should present unity of the historical and the logical, be of multifactorial nature, specific, show interplay of theory and practice, social and historical determinants of the pedagogical reality of the past. All of the above would allow to analyze the main ideas and educational practices in order to enhance teacher's training in the observed region.

The principle of objectivity should become one of the main priorities in the research. It is objectivity that cautions against subjective interpretations while doing literature review and analysis; it allows to avoid biased, groundless, ideologically charged approaches. While implementing the principle of objectivity, it is worth involving the highest possible number of sources in order to present not the fragmented and separate facts but the sets of facts that would allow to justify the stand of the author. Scientific objectivity urges to take into account a variety of various factors: socio-political, socio-economical, sociocultural, etc., which influenced emergence and development of the pedagogical education of the region in certain chronological period.

The principle of scientificity implies unveiling cause-and-effect interconnections, phenomena, processes, and events that took place in the historical period under examination. Application of the principle of scientificity adds to the comprehensive coverage of the learning material of the time (reflected in the curriculum and course material); to defining the perspectives of the use of historical legacy for reforming the modern pedagogical field; to giving an objective account of the scientific facts, phenomena, and theories of the researched period.

The principle of historical accuracy urges to study and analyze in integrated manner the historical regularities and features of development of certain pedagogical phenomenon; it allows to examine the main stages of pedagogical education development during the set historical period. Besides the principle of historical accuracy, civilization and formation principles are instrumental for comprehending a cultural and historical process. When these principles are applied, development of pedagogical education is viewed in the light of the particulars of the time (state organization, political order, economic development, available teaching staff, etc.)

Using the principle of congruity with nature is grounded on the constitutive idea of future teacher's training, on teaching and mentoring future teachers within the scope of progress of Ukrainian society and assimilation of general legacy of preceding generations. The principle of congruity with culture assumes indissoluble ties between development of the pedagogical education and nation culture, knowing the history of the nation and its forming. 
A study of the subject itself is an important factor of methodological concept of research on pedagogical history. It implies turning to a set of research methods, namely:

Empiric methods (source studies and historiographic analysis, descriptive analysis) to search, process and interpret the source material and determine the prerequisites of pedagogical education development in the region. Content analysis method is helpful in revealing the content of pedagogical education. Quantitative method is most commonly used to analyze the authentic documents (scientometric analysis of the publications' and theses titles, of archival documents and periodicals; estimation of the research works on the subject; defining the state of knowledge of a certain pedagogical problem, dynamics of changes in orientation on peculiar issues of pedagogical education in the regional dimension). Empiric methods are applied when there is a need for a search and analytic work in libraries, archives and museums. Content analysis method should be used when dealing with various documents, whether published or not. It is crucially helpful for the work in archives. For example, Soviet archiving did not have among its priorities preserving as a single body of material the documents on development of the pedagogical educational institutions of the Podillia region of Ukraine; therefore, searching for information in archival sources requires deep understanding and knowledge of prerevolutionary records management that may contain the needed data. This method, as a system of search and evaluation of the facts of historical pedagogy, was implemented through comprehensive search with subsequent classification, grouping, separating the major from the minor, evidence-based from probable. Content analysis method is exceptionally convenient when there is a need to analyze a body of historical sources on some sphere of everyday life of a society. Content analysis method is very helpful for getting the hidden information from specialized documents, such as library catalogs or reference lists. Content analysis method also helps to give an objective, systematic and quantitative description of the content of these sources. This method is well-suited for discovering necessary information about the pedagogical processes, phenomena, facts of the past, which are unavailable for direct observation.

- General methods of science (analysis, synthesis, generalization, analogy, comparison, classification, dialectic method, and method of scientific theoretical interpretation) are aimed to organize the research work, to set a goal at objective, scientific and throughout study of many factors of development of pedagogical education, including process, 
content, organization, and pedagogical ideas. The use of general methods of science to study various sources and literature "allows to recreate certain facts of the researched period with regard to the body of national and foreign research works, to the views that the prominent educators of the time had on the essence and specifics of teachers' training” (Zuziak, 2018, p. 6).

Methods of scientific analysis and synthesis become indispensable while studying the governmental policy in education, as well as its positive or negative consequences. The use of generalization method for the research on historical pedagogy allows to reveal the emergence and developmental trends of the pedagogical education of a certain region, to avoid simple copying the facts and presenting the plain chronological list of facts, events, and phenomena of pedagogical history. The use of generalization method prompts formulating the conclusions of a research thesis. Analogy method facilitates defining the common problems of the pedagogical education development. For instance, during the late 18th through the early 20th century in the Western Podillia and Eastern Podillia regions of Ukraine the common problems were: astonishing learning environment, poor learning conditions, lack of learning aids and methodology, low wages of the teachers, corruption, etc. Comparison method enables discovering specific developmental features of pedagogical education that were not typical for other territories of Ukraine, common and distinctive traits in the government policy of different regions and states. At the same time, methods of analogy and comparison are used for finding common or different elements in the curricula of the different types educational institutions during the researched period. Cognitive method is an efficient tool for working on archival sources, religious and non-religious periodicals, academic publications. Descriptive method is helpful in discovering individual features of the teacher's training at the various educational institutions in the studied region. Classification method ought to be applied to study the educational institutions for teachers' training, as it "helps to validate the classification of such institutions, typical for certain region (including religious educational institutions: seminaries, religious schools for men and women, parish schools for women, secondary-class church parish schools and schools for teachers; and non-religious: gymnasia and progymnasia, seminaries for teachers, teacher's training institute, etc.)" (Zuziak, 2018, p. 6).

To provide a proper explanation of pedagogical processes, phenomena, ideas and concepts of the past the method of interpretation is often used. While interpreting certain facts, phenomena, processes, it is possible to reveal different aspects of information about them, to assess the potential of this information for achieving the objectives of the research on pedagogical history, to make assumptions about the reasons for their emergence, to uncover the regularities, connections and trends of development of the problem. Forecasting and 
actualization methods are used to comment and determine the academic achievements of the educators of the past, as well as their failures; also to draw perspectives for theoretical and methodological research and in the field, prospects for the use of the results of this research for improvement of pedagogical education in Ukraine. In the studies on the progress of pedagogical education in the regional dimension, the dialectic method is applied, as it allows tracing the interconnections and mutual influence within the process of development of events and phenomena.

It is methodologically reasonable to use the following specific methods for the historical pedagogical matrix of the research:

- Historical-pedagogical method - to define and substantiate the concept of the research.

- Comparative pedagogy is helpful in juxtaposing the phenomena, events of historical pedagogy with the facts of socio-cultural life of the period, for revealing common and divergent in the content of the pedagogical education of the region at the different stages of its development. It is worth noting that method of comparative pedagogy enables the research of pedagogical education in different historical periods; allows to capture the features of the different evolutionary stages of pedagogical education of the region and of various social groups; identify their common, recurring and specific characteristics. For instance, comparative pedagogy may be applied for determining the main policy trends of the state authorities (Ministry of Public Education, Ministry of Religions and Education, the Holy Synod, Curator of the Kyiv Educational District, etc.).

- Problem-genetic method suits well for retrospective coverage and recreating of the pedagogical education in the researched period, as well as for substantiating implementation of historical achievements of the pedagogical education of the past into contemporary educational practice of the pedagogical higher educational institutions. This method makes a significant contribution to the process of studying the dynamics of social changes, of national and cultural life of the region; to the retrospective coverage and recreation of the system of pedagogical education of the period; to determining contradictions, lining up the cause-and effect connections and regularities of development. As this method is specific and detailed, it helps in formulating theoretical positions on the features of professional training of the future teachers at the educational institutions of the region, both religious and nonreligious ones.

- Concrete historical method is well-suited for analysis and comparison of the projects of reforms and state legislation that incorporated new 
models and paradigms of pedagogical education, as well as for developing periodization and discovering the main tendencies of the progress of pedagogical education in the region. Concrete historical method enables systematization of development of pedagogical education in chronological stages that may differ in certain ways. Application of this method enables not only analysis and comparison of the reforms' projects and state legislation, but also allows to trace changes in nearly all fields of social life of the future teachers in the region, to determine negative correlation with the impact of sociopolitical factors.

- Logical and systematic approach is suitable for highlighting the conceptual basis of pedagogical education development within the framework of overall historical progress, as its integrated social and pedagogical phenomenon.

- Method of study and generalization of pedagogical legacy reveals levels of educational work, of teachers' pedagogical skills and innovativeness, traces patterns of educational process in a certain period.

- Systemic-structural method helps in designing the structure of the research, its organizational features, as well as process and content. As it was mentioned above, pedagogical education is viewed as a system; therefore, its study is conducted by analyzing its key components and typical links between these elements. Systemic-structural method is instrumental in presenting all phenomena of historical reality and their interconnections as a single mechanism with certain features and at the same time traces their structural changes, content and evolution. It contributes to the consistency of the research and not only adds to the scope of the research material but also provides structural unity of the study. The use of the systemic-structural method allows not only to define a structure of historical-pedagogical research but also to establish connections between its elements. Systemic-structural method contributes to highlighting the sets of problematic issues and simultaneous consideration of certain events of the period; it implies division of broader subjects into the smaller ones, each one to be subsequently viewed in chronological and logical order. This is the method that helps to recreate the general tone of the era, the environment, in which students of the certain region had been learning. When applied, the method reveals the logic behind the emergence of different issues of pedagogical education of the region, contributes to consistently studying the basic phenomena, becomes a key factor for proper structuring of the research work. 
- Historical-typological method aids in typological classification of the educational institutions and recreating the key features of educational process of the time. This method allows conducting typological classification of historiographic material, analyzing sources and classifying them according to their types.

- Pedagogical biography is a method of studying the evolution of the views of prominent educators on the issues of professional training of future teachers. This method allows to characterize biographical facts, life and work, and personal traits of the noted educators, cultural religious figures, whose activity was linked to the development of pedagogical education. At the same time, pedagogical biography is also helpful in studying the staffing of educational institutions of the certain period. Official pre-revolutionary records of the teaching stuff give account of nationality, professional training, career, religious views of the teachers.

- Extrapolation method is applied for prognostic justification of creative use of progressive achievements of pedagogical education in the current realities, when reformation of pedagogical education is underway.

- Terminology analysis of the specialized literature outlines the key concepts and categories of the subject (Zuziak, 2018, p. 7).

\section{Conclusions and Implications}

Scientific analysis of the leading methodological approaches applied to a pedagogical history research (taking into account a regional dimension) allows to assert: the mentioned methods of research with regard to the key principles provide an opportunity to compare and trace the evolution and dynamics of development of the pedagogical education of the region within the defined chronological frame, shaping it as a complex, controversial process, influenced by many factors.

Theoretical and methodological basis of the research should be grounded in holistic, historical and chronological, systematic, paradigm, structural, functional, axiological, and cultural studies approaches, be generally science-based, historically accurate, congruous with nature and culture. Within the scope of these approaches and principles, appropriate research methods should be used, i.e. empirical, general-science and specialized ones.

Presented methodological approaches, principles and methods of research form a solid foundation for historical and pedagogical studies, for the set of concepts and categories to be used in them. These methodological approaches enable the pedagogical history issue of pedagogical education of a certain region to be thoroughly studied and analyzed by examining phenomena from the 
perspective of their development and interconnections, by understanding the interplay of a mindset and everyday life.

In general, integrated application of research approaches, principles and methods is instrumental for the most effective use of archival material, published documents and academic literature, periodicals. This gives way to a systematic and unbiased analysis of emergence and developmental trends for pedagogical education in its regional dimension.

\section{References}

Adamenko, O. (2013). Metodolohiia formuvannia dzherelnoi bazy istoryko-pedahohichnoho doslidzhennia [Forming a source basis for a research of historical pedagogy]. In I. Shorobyra (Ed.), Pedahohichnyi dyskurs: Zbirnyk naukovykh prats [Pedagogical discourse: Collected articles]. Khmelnytskyi Humanities and Pedagogic Academy, 10-13.

Berezivska, L. (2011). Periodyzatsiia reformuvannia shkilnoi osvity v Ukraini za Radianskoi doby (1919-1991) [Periodization of reforms in the school education of Ukraine during the Soviet era (1919-1991)]. Istoryko-pedahohichnyi almanakh: zbirnyk naukovykh prats Umanskoho derzhavnoho pedahohichnoho universytetu im. P. Tychyny [Historicalpedagogical almanac: Collected papers of the Pavlo Tychyna Uman State Pedagogical University], 1, 44-48.

Gupan, N. (2013). Aktualni problemy metodolohii istoryko-pedahohichnykh doslidzhen [Topical issues of methodology of historical-pedagogical studies]. Ridna shkola [Native school], 4-5, 53-56. Retrieved from http://nbuv.gov.ua/UJRN/rsh_2013_4-5_10

Dichek, N. (2014). Metodolohichni aspekty modernizatsii vitchyznianykh istorykopedahohichnykh doslidzhen [Methodological aspects of modernization of Ukrainian historical-pedagogical studies]. Pedahohika i psykholohiia [Pedagogy and psychology], 2 (83), 67-75.

Zuziak, T. (2018). Tendentsii stanovlennia pedahohichnoi osvity na Podilli (kinets XVIII pochatok XX stolittia) [Tendencies of development of pedagogical education in Podillia region during the late 18th through the early 20th centuries]. [Extended abstract of doctoral thesis, Poltava V.G. Korolenko National Pedagogical University, Poltava, Ukraine]. DSpace JSPUI. Retrieved from http://library.vspu.net/jspui/bitstream/ 123456789/4606/1/Avtoref_Zuzyak_28.05.18_\%d0\%bf\%d0\%b5\%d1\%87\%d0\%b0\%d1 \%82\%d1\%8c\%281\%29.pdf

Ziaziun, I. (2011a). Pedahohichne naukove doslidzhennia u konteksti tsilisnoho pidkhodu [Pedagogical research in the context of holistic approach]. Porivnialna profesiina pedahohika [Comparative professional pedagogy], 1, 19-30.

Ziaziun, I. (2011b). Tsilisnyi metodolohichnyi pidkhid u pedahohichnomu naukovomu doslidzhenni [Holistic methodological approach in pedagogical research]. In Profesiine stanovlennia osobystosti: problemy i perspektyvy: materialy VI mizh., nauk.-prakt. konf., Khmelnytskyi, 24-26 zhovtnia 2011 [Professional development of personality: Problems and perspectives: Proceedings of the 7th International Scientific and Practical Conference held in Khmelnytskyi on October 24-26, 2011]. National Academy of Pedagogical Sciences of Ukraine, Khmelnytskyi Institute for Pedagogical and Adult Education, 7-13. 
Kurylo, V., \& Khrykov, Ye. (Eds.). (2013). Metodolohichni zasady pedahohichnoho doslidzhennia: monohrafiia [Methodological basis for pedagogical research: A monograph]. Luhansk Taras Shevchenko National University, 109-245.

Sukhomlynska, O. (2003). Istoriia pedahohiky yak nauka i yak navchalnyi predmet: aktualni problemy [Historical pedagogics as a science and as an academic discipline]. Shliakh osvity [Education Path], 1, 39-43. 


